Western University Scholarship@Western

Political Science Publications

Political Science Department

Fall 8-23-2016

\title{
Towards a World Free of Nuclear Weapons
}

Erika Simpson

Western University, simpson@uwo.ca

Follow this and additional works at: https://ir.lib.uwo.ca/politicalsciencepub

Part of the Defense and Security Studies Commons, and the International Relations Commons

Citation of this paper:

Simpson, Erika, "Towards a World Free of Nuclear Weapons" (2016). Political Science Publications. 145.

https://ir.lib.uwo.ca/politicalsciencepub/145 


\section{Erika Simpson, "Towards a World Free of Nuclear} Weapons" Peace Review: A Journal of Social Justice, vol. 28, no. 3, pp. 309-17, August 2016, and/or Scholarship Western: This is a preprint of an accepted and published manuscript of an article published by Taylor \& Francis and the accepted manuscript will be posted after the embargo is done on Scholarship Western: DOI 10.1080/10402659.2016.1201946

\section{By Erika Simpson}

North Korea announced it conducted a nuclear test of its first hydrogen bomb on January 6 and on February 72016 it fired a long-range rocket which critics said was a test of banned missile technology. The Great Powers are pointing accusatory fingers at Pyongyang, but they should point fingers back at themselves. Though the global total has been cut to 15,850 nuclear weapons, 95 per cent of the world's nuclear arsenal belongs to the U.S. and Russia. The U.S. and Russia still retain more than 5,000 nuclear weapons on alert, ready to launch in minutes, and now China is said to be contemplating putting its smaller nuclear arsenal on hair-trigger alert, too.

We no longer hear much about the revived Cold War and the dangerously pre-emptive doctrines of China, France, Russia, the United Kingdom and the United States. Instead academics, diplomats and media pundits tend to focus on criminal elements in Russia bent on stealing plutonium, rogue states like North Korea and Libya, and terrorists in al-Qaida or ISIL intent on purchasing nuclear weapons on the black market. Yet the sheer enormity of the size and cost of the arsenals belonging to the former superpowers simply defies human comprehension. And their modernization programs will ensure that nuclear weapons, costing more than $\$ 100$ billion a year, are retained for the rest of the 21st century.

There needs to be much more vigorous progress on American and Russian arms control and disarmament. The Russians are considering deploying nuclear weapons in Kaliningrad, its enclave close to the Baltic countries. Meanwhile, the Germans are wondering whether to agree to the U.S. proposal to modernize the bombers that carry NATO's tactical B-61 nuclear weapons. London's ruling Conservative party and Edinburgh's Scottish National Party disagree about the modernization of the U.K.'s 
Trident nuclear submarines. France has rejoined NATO but its independent nuclear arsenal seems to reassure only Parisians.

We must reassess the Great Powers' and NATO's reliance on nuclear deterrence strategy. The United States' allies need to ask themselves in the months leading up to NATO's seventieth anniversary in 2019 and the 2020 Nuclear Non-Proliferation Treaty (NPT) Review Conference whether nuclear weapons actually protect them. Does the possession of nuclear weapons deter potential aggressors from attacking? Curiously, the leaders of the non-nuclear weapon states (NNWS) in NATO continue to profess their reliance on traditional nuclear deterrence, while the U.S. moved years ago toward a pre-emptive strategy that promises to strike first with nuclear weapons, even in the event of a limited chemical or biological attack. The situation is similar to the late 1950s and 1960s when all the NATO allies continued to rely upon one permutation of nuclear deterrence-mutual assured destruction or MAD - even as the U.S. developed another permutation called 'flexible response'.

To clarify, NATO's 'new' Strategic Concept was asserted in 1991, reissued in 1999 and reconfirmed in 2000-2010. It links the NNWS that shelter under NATO's umbrella to the overall nuclear policies of the NATO Nuclear Weapon States (NWS). Over the last fifteen years, significant pressure to change NATO's nuclear posture emanated from coalitions of states and nongovernmental organizations, including the Article VI Forum, the International Campaign to Abolish Nuclear Weapons (ICAN), the Middle Powers Initiative (MPI), the New Agenda Coalition (NAC), the Non-Aligned Movement (NAM) and Parliamentarians for Nuclear Non-Proliferation and Disarmament (PNND).

Diplomats and high-level NGO representatives involved in the NPT Review Conferences, held every five years, often debated the implications of the NPT's 'Article VI' commitment for NATO's Strategic Concept. Diplomatic debates also took place during NPT Preparatory Committee Meetings and NPT Review Conferences. The founding chairman of the MPI and its Article VI Forum, Canadian Senator (ret'd) Douglas Roche argued that since states, including all NATO member states, endorsed the NPT, NATO could no longer claim its nuclear weapons were "essential". NATO headquarters was urged by many to rethink its policy but the Strategic Concept was reaffirmed stating that, "As long as nuclear weapons exist, NATO will remain a nuclear alliance."

Many bureaucrats, defence ministers, and parliamentarians continue to believe that to ensure peace and prevent conventional war or coercion, the alliance has to maintain for the foreseeable future "an appropriate mix of nuclear and conventional capabilities." NATO's 2012 Deterrence and Defence Posture Review reasserted that nuclear weapons are the "supreme guarantee of the security of the alliance." Given the Great Powers' continued reliance on nuclear deterrence, it was no surprise that the 2015 NPT Review 
Conference ended in debacle and deadlock with no agreement on a final consensus document.

Faced with Russian recalcitrance over Crimea and Ukraine, NATO has begun to strengthen its conventional and nuclear defences along the Polish and Baltic borders and modernize the bombers that carry B-61 tactical nuclear weapons. Russia announced in September 2015 it might deploy nuclear missiles to Kaliningrad on the Baltic Sea if the US upgraded its nuclear weapons in Germany.

Some sort of in-depth review of NATO's nuclear doctrine, perhaps in time for NATO's seventieth anniversary celebrations in 2019, should be demanded. Changes in the Strategic Concept might also be requested once another U.S. President is elected but we need to remember that efforts to change NATO's deterrent policy can begin at the national level among NATO's allies. The thrust for NATO's 1999 review essentially began because Canada's parliament released a report calling for a re-examination of NATO's reliance on nuclear deterrence and the Strategic Concept. Canada's then Foreign Minister Lloyd Axworthy committed his department to attempt to change NATO's nuclear doctrine - for which he was often labelled a 'nuclear nag.' Working together with Joschka Fisher, the German Foreign Minister, these critics of NATO policy attempted to persuade NATO diplomats that the alliance needed to reconsider its reliance on nuclear weapons for deterrence purposes. Even some high-level American diplomats at NATO headquarters were impressed with the Canadian-German initiative and the determination of the Canadian Foreign Minister and his diplomatic aides. In a similar fashion, working together with other like-minded middle powers, such as Germany, Norway, Belgium, and the Netherlands, it might be possible to push for a reassessment of NATO's nuclear doctrine.

We must also work toward total denuclearization and demilitarization of the entire Korean peninsula as the best long-term solution. In the shorter-term, we must press China to try to exert the upper hand in peaceful negotiations. All state parties should press Chinese officials to reign in Kim Jong-Un and lay before him a comprehensive deal with economic incentives and disincentives, and many security guarantees.

However, the international community must expect any comprehensive deal could be ignored, jettisoned or violated. Therefore the most-threatened citizens of China, Japan, Russia, South Korea and the United States should take the initiative and demand a halt to North Korea's sabre-rattling. We all need to change North Korea's payoffs so it wants to cooperate, rather than defect. The international community should dangle greater incentives and disincentives so North Korea perceives its pay-offs - the merits of cooperation and the demerits of defection - to be far higher. 
We should also press the U.S. to offer to drastically reduce the number of American soldiers stationed in South Korea. If the U.S. promised to withdraw tens of thousands of American soldiers - as it has withdrawn them in gradual reductions from Afghanistan, Iraq and Vietnam - the forces could be used as a bargaining chip in any bilateral, trilateral or multilateral negotiations. If the U.S. offered to take home its approximately 28,500 forces, in staged withdrawals, it could always threaten to move them back to Japan and South Korea.

The U.S. would still need to credibly deter Kim Jong-un - or the dynasty's next familial successor - by threatening to use powerful and precise conventional weapons in the unlikely event of an armed attack streaming over the Korean demilitarized zone at the $38^{\text {th }}$ parallel. In future, the South Korean army should also be trained to refrain from relying on the use of U.S. anti-personnel land mines.

Calling for interim milestones and measurable lower outcomes - rather than a comprehensive agreement - would be a practical way for global citizens to contribute to dialogues about the two Koreas. Another option worth talking about is that North Korea's closest geographical neighbors - China, Japan, Indonesia, South Korea and Taiwan - set up an ASEAN-derived alliance, similar to the NATO alliance. A new collective defense alliance could promote an Asian Community of shared values, similar to the way in which the Washington Charter's Article II - oft referred to as the Canadian article - promoted Western social, economic and political values. In the long run, more efforts to welcome North Korea into the Asian community might reap unexpected benefits for the entire world.

North Koreans should also be expected to take a seat at multilateral tables on issues that affect China. Indeed, North Korea could learn from the example of so many other nuclear-free states and decide to become nuclear weapon free, relying on China's nuclear umbrella instead. About 55 percent of the world population lives under a nuclear umbrella. If we can exert an impact on North Korean thinking about nuclear weapons so they understand the logic of the nuclear taboo as well as mutual assured destruction, we might make a long-term difference to their calculations.

As a prelude to state visits by Kim Jong-Un to Hiroshima and the UN in New York City, perhaps other world leaders could follow the lead of U.S. Secretary of State John Kerry, the most senior American official to travel to Hiroshima, and Canadian Foreign Affairs Minister Stephane Dion by visiting Hiroshima Peace Memorial Park in Hiroshima. Perhaps world leaders, like Canadian Prime Minister Justin Trudeau could invite Kim Jong-Un to visit Ottawa, and its Cold-war era bunker in Carp now open as a museum. Less formal invitations can open more productive dialogue, leading to possible détente on the Korean peninsula. 
In all such formal and information discussions, if the fundamentals of the Iranian deal could be treated as a template for all countries, the international community would be well on its way to choking off the supply of weapons-usable material everywhere.

Within the existing framework of international law, the Iranian deal is as good as we can expect. We should help the UN fully implement the agreement, and its other associated obligations, and engage with the International Atomic Energy Agency (IAEA) to achieve concrete results on all outstanding substantive issues, as required in the binding resolutions of the IAEA Board of Governors, and the mandatory UN Security Council resolutions.

But we must do more than urge the UN, the IAEA and the OEWG to help implement the agreement. Hopefully the deal with Iran could serve as a template for similar agreements with the DPRK, India, Pakistan and possibly Syria. The terms of the agreement should be widely lauded - it could become the template for dealing with other secret proliferators.

In the interim, all the proliferators that refuse to sign the NPT and accept the strictest safeguards of the IAEA - like Israel, India, North Korea and Pakistan - should be sanctioned, like Iran. By banning uranium exports to NPT non-signatories as a first step, countries like Canada, South Africa and the United States would lose money on lucrative sales of uranium but then they would be able to insist on separating civilian and military nuclear facilities and programs, placing the former under IAEA safeguards; ensure more intrustive inspections of these facilities; support negotiations toward a Fissile Material Cut Off Treaty; help adopt an additional protocol; and support the goal of eliminating nuclear weapons and the negotiation of a convention toward that end.

It is time for the people in the Middle East that would be most affected by use of Iranian or Israeli nuclear bombs - five, fifteen or twenty-five years from now - to take steps to avoid a nuclear arms race in the Middle East. They should also sanction Israeli exports until Israel, a long-time non-signatory of the NPT, becomes compliant to NPT protocol and transparent about its clandestine 80-100 tactical nuclear weapons. In the long run Israel must recognize the necessity of declaring itself a nuclear power - and subject to IAEA inspection. Accordingly, multiple constituencies, including youth, parliamentarians, mayors and peace and disarmament advocates should call on proNetanyahu forces to abide by the international community's rules.

The overall imperative remains that the entire nuclear regime, especially its cornerstone treaty, needs much stronger debate and qualified support. In addition to Israel, the American, Canadian and British governments' delegations to the Conference 
on Disarmament in Geneva should take steps to make amends for their recalcitrance in May 2015, and vow to make sea-changes in their approaches to arms control and disarmament.

All the countries possessing nuclear weapons need to be criticized for their recalcitrance by those people living under extended nuclear deterrence relationships (the 'nuclear umbrella countries'), by the non-nuclear countries, as well as by their own constituents, many of whom themselves did not heard anything in the news about the NPT debacle in 2015.

In order to secure the continuation of the NPT regime past 2020 - which is especially important since the negotiations in April-May 2015 failed - there is an even greater urgency to take immediate steps towards establishing a zone in the Middle East free of Weapons of Mass Destruction. The NPT 2010 Action Plan on the Middle East must be implemented without delay, including by convening a people's conference on the Middle East that plans to establish a zone free from nuclear weapons and weapons of mass destruction. People from different diaspora in the world, particularly from Egypt, Iran, Israel, Saudi Arabia, and Turkey should be encouraged to participate in multilateral and bilateral preparatory conferences. There should be large-scale conferences prior to the NPT Preparatory Conferences and the 2020 NPT Review Conference.

Further multilateral and bilateral meetings should be held in the Middle East, and also in Geneva, New York City and Vienna. Then in 2019, in New York City at the UN, the international community should tackle any remaining issues that defy resolution so that the 2020 NPT Review Conference does not once again end in debacle and disagreement.

We should compliment Ambassadors, like Finland's Ambassador for organizing so many meetings prior to 2015 in New York - and we should urge like-minded states to lend considerable political support to the delegations of Austria. Costa Rica, Egypt and Finland in their endeavors. Clearly more political will and impetus are needed among Ambassadors representing countries in the Middle East.

It is time to call upon the people represented by Egypt, Iran, Israel, Saudi Arabia and Turkey to demand their Ambassadors immediately visit each other's parliaments and legislatures with a view to rapprochement and peace.

$\mathrm{A}_{\mathrm{t}}$ the same time as we work toward establishing a zone free of weapons of mass destruction in the Middle East, we should discuss creating a Nuclear Weapon Free Zone (NWFZ) in the Arctic. It could take years to overhaul international law governing military activities, resource extraction and sovereignty in the Arctic, but global citizens including representatives of Indigenous Nations could take one important step by 
initiating discussions to establish a nuclear-weapon-free zone covering the Arctic. In such a zone, the development, testing, manufacture, production, possession, stockpiling and transportation of nuclear weapons would be prohibited. The use or threat of use of nuclear weapons against nations and areas within the zone would also be prohibited. And a permanent organization would be established to ensure compliance.

There are already many regional nuclear-weapon-free treaties around the world, covering large swaths of Central and Latin America, Southeast Asia, Africa and Central Asia. Each commits the states not to deploy, construct, receive or test nuclear weapons on its territory. Already 113 nations - a majority of UN members - have signed or ratified these treaties, and 50 percent of the world's land area, including Antarctica, is governed by these treaties.

Two other treaties are relevant to the Arctic case: the Antarctic Treaty of 1959 prohibiting all nuclear activity on that continent and the 1971 Seabed Treaty prohibiting the stationing of nuclear weapons or support facilities on the seabed outside a country's territorial waters. Youth, parliamentarians and indigenous representatives could remind us that both treaties seemed out of reach at one time; now they are honored by all the world's states.

As a first step, some suggest Indigenous people from the four Nordic countries, potentially followed by Canada, could officially declare their territories free of nuclear weapons, since that is already the case. However it starts, the vision is that someday the territories, waters and melting ice cap covered by this kind of zone would expand until it covers the total land and waters north of the Arctic Circle.

The main obstacle to an Arctic zone is that the region continues to serve as a key arena in the U.S.-Russian military standoff. The U.S. and Russia still routinely conduct nuclear-powered submarine patrols there. Both states consider their submarine operations highly classified - the U.S. Navy has a long-standing, inflexible policy of refusing to confirm or deny the presence of nuclear weapons on its warships. Both nations also have nuclear-capable aircraft that fly over the Arctic. While the number of patrols dropped off at the end of the Cold War, Russian bombers continue to make Arctic overflights close to the coasts of Canada and the U.S.

It would be in the interest of all the Arctic Council members - Russia, the United States, Canada, Denmark, Finland, Iceland, Norway and Sweden - to reach agreements on how to handle resource development in the region. Given the devastating consequences of a nuclear accident in the Far North, however, there needs to be immediate broad discussion about establishing an Arctic NWFZ. 
Russia is attaching growing importance to the Arctic for maintaining a nuclear deterrent against the United States. Russia's Northern Fleet, based in the Arctic and equipped with nuclear weapons, is seen by the government as its most important naval asset. Russia is planning a new generation of submarines based at its Arctic ports. Russia opposes participation by Indigenous representatives and observers at the Arctic Council meetings but they are needed to draw much greater attention to the dangers in their constituencies of a nuclear arms race in the Arctic.

Still we face another obstacle: five Arctic states are members of NATO and by treaty subscribe to its nuclear doctrine. The deterrent provided by NATO's three states with nuclear weapon - the U.S., Britain, and France - is obsolete and counterproductive to co-operative security in the post-Cold War world, but it is unlikely the allies without nuclear weapons will take the initiative to substantially change NATO's doctrine. A pessimistic appraisal is that only substantial progress in U.S.-Russian arms control talks will create the conditions for a change in NATO doctrine and Arctic policy. For diplomats in NATO, Russia's takeover of Crimea could prove to be another obstacle. But putting in place an effective and enforceable Arctic zone would not need require a sea change in U.S.-Russian relations. We are already seeing a huge change worldwide concerning the credibility and viability of using nuclear weapons.

As we teach each other about the Arctic's fragile environment and the long-lasting impact of a possible nuclear accident, it is not too soon to bring the campaign for an Arctic nuclear-weapon-free zone to the UN, governments and civil society in all Arctic nations, as well as other states and indigenous peoples. Deploying and possibly using nuclear weapons in the environmentally sensitive Arctic must be viewed as having very little credibility. It is also morally repugnant to future generations.

In calling for an Arctic nuclear treaty, we need to be aware of the magnitude of the effort needed to achieve it and the historic compromises required. But an Arctic NWFZ would be an important step forward for people from all over the world, different cultures and countries, to take.

More options - which rely less on state-level change and more on parliamentary bodies and civil society - are to call for members of parliaments and legislatures around the world to support a Nuclear Weapons Convention (NWC), which would be a global treaty to prohibit and eliminate nuclear weapons in a way similar to the Chemical Weapons Convention (CWC) and the Biological and Toxic Weapons Convention (BTWC). In Canada, more than 800 members of the Order of Canada, including most recently former prime minister Jean Chretien, have endorsed the idea of a NWC, and such a parliamentary motion unanimously passed both the Senate and House of Commons in 2010 under the Conservative government led by Stephen Harper. 
We should also support the further building of worldwide networks including PNND, the OEWG and ICAN. The OEWG held its first formal meetings in Geneva between February 22-26 2016 at the long-stalled UN Conference for Disarmament and there is some hope the fledgling group will make painstaking progress toward negotiations that attain and maintain a world without nuclear weapons.

With assistance from the International Campaign to Ban Nuclear Weapons, many groups and their representatives are working on constructing a treaty banning nuclear weapons, even though such a ban would not be legally binding on the nuclear states. Developing a legal ban, even without the participation of the nuclear weapon states, would strengthen the global norm against nuclear weapons.

Stigmatizing nuclear weapons states might incite more countries to sign the Humanitarian Pledge, which commits countries to work toward a ban on nuclear weapons. Already 123 nations - but not NATO allies - have signed it and it could lead to more active negotiations for a nuclear weapons convention. Agreeing on a nuclear ban seems a lofty goal, far into the next century, but lofty goals like ending slavery, colonialism, and apartheid once seemed unobtainable, too.

As Douglas Roche, former Canadian Senator and former Canadian Ambassador for Disarmament points out, in the last century it seemed impossible that independence would come to India in 1948 through the rise of a non-violence movement led by Mahatma Gandhi. Martin Luther King spearheaded the civil rights movement but never saw civil rights legislation passed in the U.S. in 1964. The Cold War generation failed to predict the fall of the Berlin Wall in 1989 and the subsequent collapse of the bipolar system. Nelson Mandela never expected, after 27 years of imprisonment that he would see apartheid in South Africa give way in 1993. In this century, we must push the real nuclear powers toward a global ban of all nuclear weapons.

Dr. Erika Simpson is Associate Professor of International Relations at Western University and the author of the book NATO and the Bomb, and numerous scholarly articles available at Scholarship@Western and Erika Simpson's blog. She is a regular columnist for Postmedia, Canada's largest newspaper chain (2013-16) and the VicePresident of the Canadian Peace Research Association (2015-17). A member of the Board of Directors of Pugwash Canada, she served previously as the Vice-Chair (2007-09 and 2009-11) and Treasurer (2003-05 and 2005-07) of this wealthy charitable organization. She has served as a Social Sciences and Humanities Research Council of Canada Insight Development Grant adjudicator (2011-13) and a Canadian Institute for Military and Veteran Health peer reviewer (2013-16). In 2015 she was awarded the "Shirley Farlinger Award for Peace Writings" by Canadian Voice of Women for Peace, an NGO with consultative status at the UN. 


\section{Recommended Readings}

Dallaire, Romeo and Erika Simpson. 2014. "Freezing out the nukes." Special to QMI Agency (May 3). Available at Scholarship@Western

http:/ /ir.lib.uwo.ca/cgi/viewcontent.cgi?article=1072\&context=politicalsciencepub

Datan, M., Hill, F., Scheffran, J., \& Ware, A. (2007). Securing Our Survival: The Case for a Nuclear Weapons Convention. International Physicians for the Prevention of Nuclear War, Available at The Lawyers Committee on Nuclear Policy:

http://lcnp.org/mnwc/index.htm (2015, Oct 10)

Moon, UN Secretary-General B. (2013, Jan 18). The United Nations and Security in a Nuclear-Weapon-Free-World: The Secretary-General's five point proposal on nuclear disarmament, available at UNODA website:

http://www.un.org/disarmament/WMD/Nuclear/sg5point.shtml (2015, Oct 10)

North Atlantic Treaty Organization. (2012, May 21). Deterrence and Defence Posture Review. Available at: http://www.nato.int/cps/en/natolive/official_texts_87597.htm (2015, Oct. 10).

Roche, D. (2005). Beyond Hiroshima. Ottawa: Novalis Publishing.

Simpson, Erika. 2001. NATO and the Bomb. Montreal and Toronto: McGill-Queen's University Press. 